\title{
BLACK WOMEN THROUGH ALICE WALKER'S POETRY (A CHARACTERIZATION OF THE VALUATING SUBJECTS OF HER POEMS)
}

\author{
Yeni Hechavarría Urquiaga and Yadelys Garriga Cruz \\ Equipo de Servicios de Traductores e Intérpretes (ESTI) \\ Group of Semantic, Ideographic and Discourse Studies of the School of Foreign \\ Languages of the University of Havana \\ yeni.hechavarria@esti.cu; yeni.urquiaga@gmail.com \\ yadelys.garriga@esti.cu; marcosalicia2014@gmail.com
}

Recibido: $15 / 05 / 2015$

Aceptado: 03/06/2015

\section{Resumen}

Indudablemente, el discurso literario, particularmente la poesía, es algo bello y placentero para los ojos y los oídos; es también una herramienta poderosa para expresar ideas de carácter social, cultural y político. Este trabajo en particular se centra en la obra poética de Alice Walker y está dirigido a identificar aspectos de la ideología de la mujer afro-estadounidense como grupo en la poesía de esta autora. Como miembros del Grupo de Estudios Semánticos, Ideográficos y del Discurso de la Facultad de Lenguas Extranjeras de la Universidad de La Habana (FLEX), las autoras del trabajo decidieron acudir al análisis de discurso dimensional para llevar a cabo su investigación, y para ello se basaron en la teoría del doctor Leandro Caballero Díaz sobre las dimensiones del significado y las macrocategorías semánticas modales redefinidas por la doctora Ana María Galbán Pozo en su tesis doctoral. Este fue el primer acercamiento del grupo al discurso poético, centrando el análisis en los enunciados valorativos implícitos con contenido ideológico.

PALABRAS CLAVES: discurso, ideología, macrocategorías semánticas, dimensiones modales.

\begin{abstract}
No doubt, literary discourse- particularly poetry - is a beautiful thing, pleasant for eyes and ears. We shouldn't doubt either that it is a powerful means used to convey social, cultural and political ideas. This work is focused on Alice Walker's poetry. It is aimed to find aspects of the ideology of the African-American women as a group in the poetry of this author. As members of the Group of Semantic, Ideographic and Discourse Studies of the School of Foreign Languages of the University of Havana (FLEX), the authors of this paper decided to make use of the dimensional discourse analysis to carry out their research. Thus, the work has followed the theory on the meaning dimensions and the modal semantic macrocategories introduced by Leandro Caballero Díaz, later on redefined by Ana María Galbán Pozo. Ours was the first approach to poetic discourse in our group, centering our analyses on the implicit valuating utterances with ideological content.
\end{abstract}

KEYWORDS: discourse, ideology, semantic macrocategories, modal dimensions.

\section{Introduction}

Literature is not only pieces of writing having excellence of form and expression. As a matter of fact, it is one of the most important sources of knowledge humanity can count on. Literature helps us travel back and forth in time, providing us with valuable elements of our 
present and past history, including that of our ancestors, their ways of thinking, their lifestyles, their luck and misfortune. Thus, the new generations begin to forge their own destiny.

Literature is not exclusive of any given community or culture; it actually embraces uncountable cultures with different characteristics. In our paper we are going to deal with African-American literature, especially that of black women. In order to accomplish our goal, we will focus on the work of one of those authors who has devoted a considerable part of her life to writing about her origins, beliefs and sufferings. An incredible woman who has gained world recognition due to her unique way of writing and her constant battle against black women's discrimination: Alice Walker.

According to the sources we have consulted, there have been plenty of works concerning Alice Walker's prose, especially her novel The Color Purple (1983). However, in terms of Walker's poetry, it has been difficult for us to find information. In addition, no previous reseach about Walker's poetry has been carried out in our Group of Semantic Studies, and that is one of the reasons why we have felt motivated towards this subject.

As literature is one of the written representations of language in which communicative intentions, ideologies and emotions of the authors are present, discourse is a relevant aspect to be taken into consideration when approaching it. That is why we have decided to use discourse analysis as a tool to analyze Walker's poems from her work Her Blue Body: Everything We Know Earthling Poems (1992) which is a compilation of six books.

The problem of this research was how to establish the ideological intentionality of the African American valuating subject in Alice Walker's poems. The main objective was to demonstrate through discourse analysis of the valuating subject in Alice Walker's poems, some aspects of the ideology of African American women as a group. Therefore, the object of study of the paper is the ideology of African American women as a group reflected in Alice Walker's poetry.

Before beginning the analysis of the poems selected, we will make reference to the biography of the author and the history of the Black Feminist Movement. In like manner, we'll address different criteria of discourse analysis, ideology and society, and the link among them. Likewise, we are going to refer to the Valuation Theory.

\section{Alice Walker}

Alice Walker is a relevant African-American writer who has devoted her entire life to women's defence. She was born in Eatonton, Georgia, on February 9, 1944. It is through her prose, both fiction and non-fiction, that Walker has found her most faithful audience and has established the subject matter of her work, which consistantly reflects her concern about racial, sexual, and political issues, mainly related to black women's struggle for survival. Among her prose we can find: In love and Trouble: Stories of Black women (1973), You Can't Keep a Good Woman Down(1981), and The Color Purple (1983), her most famous work and winner of both an American Book Award and a Pulitzer Prize for fiction.

However, despite the fact that she is worldwide known as a prolific novelist, she is also an accomplished poet. She began her professional career as a poet, and has continued, though less prolifically, to publish volumes of verse, among which we can mention Once (1968), Revolutionary Petunians and Other Poems (1973), Good Night Willy Lee, I'll See You in the Morning (1984), and Horses Make a Landscape Look More Beautiful (1984). Her work is 
deeply rooted in the oral tradition.

\section{Black Feminism: Womanism}

Black Feminism essentially argues that sexism and racism are inextricable from one another. Forms of feminism that strive to overcome sexism and class oppression, but ignore or minimize race, can perpetuate racism and thereby contribute to the oppression of many people, including women. Black feminists argue that the liberation of Black women entails freedom for all people, since it would require the end of racism, sexism, and class oppression.

The current incarnation of Black Feminism is a political/social movement that grew out of a sense of feelings of discontent with both the Civil Rights Movement and the Feminist Movement of the 1970s. Not only did the Civil Rights Movement primarily focus only on the oppression of black men, but many black women faced severe sexism within Civil Rights groups such as the Student Nonviolent Coordinating Committee. Besides, The Feminist Movement focused on the problems faced by white women who advocated social changes such as woman's suffrage. This movement focused largely on oppressions based on sexism, but it ignored oppression based on racism and classism. Neither movement confronted the issues that concerned black women specifically. Because of their intersectional position, black women were being systematically disappeared by both movements. Thus, the need of the term womanism arose.

The word womanism was adapted from Pulitzer Prize winning author, Alice Walker. In her book In Search of Our Mothers' Gardens: Womanist Prose, Walker used the word to describe the perspective and experiences of African American women who descended from Africa.

In this same book, she defines a womanist as:

1. From womanish (Opp. of "girlish," i.e., frivolous, irresponsible, not serious) A black feminist or feminist of color. From the black folk expression of mothers to children, "you acting womanish," i.e., like a woman. Usually referring to outrageous, audacious, courageous or willful behavior. Wanting to know more and in greater depth than is considered "good" for one. Interested in grown-up doings. Acting grown-up. Being grown up. Interchangeable with another black folk expression: "you trying to be grown." Responsible. In charge. Serious.

2. Also: A woman who loves other women, sexually and / or nonsexually. Appreciates and prefers women's culture, women's emotional flexibility (values tears as natural counter balance of laughter), and women's strength. Sometimes loves individual men, sexually and / or nonsexually. Committed to survival and wholeness of entire people, male and female. Not a separatist, except periodically, for health. Traditionally Universalist, as in: "Mama, why are we brown, pink, and yellow, and our cousins are white, beige, and black?" Ans.: "Well, you know that colored race is just like a flower garden, with every color flower represented". Traditionally capable, as in: "Mama, I am walking to Canada and I am talking you and a bunch of other slaves with me." Reply: "It wouldn't be the first time"

3. Loves music. Loves dance. Loves the moon. Loves the spirit. Loves love and food and roundness. Loves struggle. Loves the Folk. Loves herself. Regardless

4. Womanist is to feminist as purple is to lavender. 
The roots of theological womanism grew out of the theology of James Hal Cone, Jacquelyn Grant, and Delores Williams. The latter suggested that womanists theologians need to "search for the voices, actions, opinions, experience, and faith" of black women in order to experience the God who "makes a way out of no way." In her book Sisters in the Wilderness (1995), she defines womanism in the following way:

Womanist theology is a prophetic voice concerned about the well-being of the entire
African American community, male and female, adults and children. Womanist theology
attempts to help black women see, affirm, and have confidence in the importance of their
experience and faith for determining the character of the Christian religion in the African
American community. Womanist theology challenges all oppressive forces impeding black
women's struggle for survival and for the development of a positive, productive quality of
life conducive to women's and the family's freedom and well-being. Womanist theology
opposes all oppression based on race, sex, class, sexual preference, physical ability, and
caste.

With the increasing use of the term in Master of Divinity, African American Studies, and Women's Studies, programs have clearly began to incorporate womanism into university and seminary courses. One example of an educational institution that incorperates womanism in their graduate coursework is Eden Theological Seminary in Saint Louis, Missouri.

Professionals such as historians are regarded as "womanist" historians if they have incorporated the views and experiences of African American women in their accounts of history.

\section{Discourse Analysis}

Providing a comprehensive definition for discourse is a difficult task since numerous authors and linguists have referred to it. One starting point was the definitions provided by the Encarta Dictionary 2007 and the Webster's Dictionary ( $7^{\text {th }}$ new collegiate edition: 238). We found that those definitions were mostly terminological; meanwhile, there were others referring to the social aspect of discourse. For instance, Toril Moi ${ }^{1}$ provided a different definition of discourse in her book Sexual and Textual Politics. Feminist Literary Theory; in which she describes discourse as:

"[...]the social activity of making meanings with language and other symbolic systems in some particular kind of situation or setting." (1985:6)

In this book, the author also refers to the importance the participants have in this activity regarding the role they may play, whether they may speak or write, or only listen or read, and whether they are considered actually present in or only potentially relevant to the situation.

In addition, other linguists have highlighted the importance of the participants in this process of production of discourse. For example, Hatim and Mason refer to discourse as "modes of speaking and writing which involve participants in adopting a particular attitude towards areas of socio-cultural activity" (2013: 240).

1 Toril Moi is Professor of Literature and Romance Studies at Duke University. She works on feminist theory and women's writing; on the intersections of literature, philosophy and aesthetics; on finding ways of reading literature with philosophy and philosophy with literature without reducing the one to the other. 
After having analyzed all the concepts previously presented, we have reached at the following conclusion:

\section{Discourse is the production of meanings in the process of communication. It is condi- tioned by the ideologies, the personal experiences and the communicative intentions of the participants in a given socio-cultural context.}

We consider that it is important to point out that discourse is not only oral, there is also written discourse (as there are oral texts). In fact, discourse and text are two different concepts, although undoubtfully linked. Referring to this aspect, R. Fowler expresses in his book "Linguistic Criticism" that:

To look at language as text entails the study of whole units of communication seen as coherent syntactic and semantic structures which can be spoken or written down. Discourse is the whole complicated process of linguistic interaction between people uttering and comprehending texts. (1996:111)

Consequently, it is necessary to take different criteria or methods into consideration when analyzing text or discourse.

Professor Patrick Charaudeau (1998) proposed three ways for analyzing discourse:

1. The study of discourse as a production mechanism inherent to texts resulting from the process of enunciation.

2. The study of discourse as an empirical object which allows us to determine the different types of discourse (politic, didactic, scientific, etc).

3. The study of discourse as social representation, as manifestation of ideological positions, power relations, etc.

The criterium we have selected to carry out our analysis is the one concerning the study of discourse as social representation, due to the fact that our work is going to be focused on the ideology of a specific social group, and how it is reflected through the discourse of one of its members: Alice Walker. Referring to the importance of discourse analysis, Ana Curbeira expresses that it "highlights the fact that the use of language and thinking are typically and functionally expressed in the social discursive interaction" (2003:167) (translated) ${ }^{2}$. On the other hand, Van Dijk considers discourse analysis is:

An autonomous discipline capable of providing the most efficient way to study the langua-
ge, analyze cognition, study the interaction and social structures not as different things, but
as different aspects of a single and more complex scientific venture: discourse's description
and explanation. (2003: 167)

For us, discourse analysis is of great importance because it is a way to analyze not only how the author expressed their ideas, but also what is between the lines, that is, the speaker/ author's intentionality.

2 All translations in the paper have been made by the authors. 
All this analysis is done through utterances which are communicative units made up of one or more speech acts (considered to be dynamic units of discourse) that as a whole convey a given meaning.

The production of a speech act is conditioned by different factors:

- The person that emits discourse and the receiver, who have a common cultural background.

- The psychological and illocutionary positions of both participants.

- The production conditions of the discursive activity.

- The reality that serves as element of communication.

There are two types of speech acts: direct and indirect.

Direct speech acts are those in which the communicative intention is explicitly stated. On the contrary, in indirect speech acts the communicative intention of the person that produces discourse is implicit.

There are different authors who have proposed diverse criteria of classification of speech acts. For example, Austin (1962) and Searle (1969) introduced different taxonomies to classify speech acts such as: the locutionary, illocutionary and perlocutionary speech acts, which are directed to the analysis of the intention of what is being said and the effect it has upon the receptor.

In later studies, the illocutionary speech acts (which express the intentionality in discourse) have received most detailed attention, and there have been many attempts towards creating an effective and comprehensive typology. Austin suggests a model of analysis where the illocutionary acts are distinguished according to the illocutionary force (which lies in the intention of the person that produces discourse and the interpretation of the receiver) associated with each class. These speech acts are denominated: verdictives, exercitives, commissives, behaviotives, and expositives. Following Austin`s studies, Searle basically uses the same model of analysis and improves it in a more reasonable and methodic way. He named the speech acts as follows:

- Assertive: the function of these speech acts is the one of representing a state of present, past, future or hypothetical events.(Austin`s expositive, and verdictive)

- Directive: they are used to have the receiver do what the agent is saying. (Austin's exercitive)

- Commissive: they commit the receivers to do something. (Austin`s commissive)

- Expressive: they only express the psychological state of the agent. (Austin`s behaviotive)

- Declarations: they are used to put into practice the agent's authority. (Austin`s exercitive).

Furthermore, Austin also reached crucial conclusions when approaching the study of speech acts. They were related to some necessary conditions for the optimum realization of speech acts, which he named felicity conditions, later modified by some other authors as appropriateness conditions, stating that the term used by Austin was more connected to 
philosophic studies. These conditions were analyzed in detailed by Searle (1969:123-124) who divided them into three major groups:

- Preparatory conditions: in which the person that produces the speech act must have the authority to do it. Besides, it must be the appropriate situation to do so. These are typical conditions of evaluative speech acts in which the valuating subject must have a social status that confirms them as a person capable of evaluating.

- Sincerity conditions: in which the person that produces the illocutionary speech act should do it by his own will. If it is not so, the person could be lying. These conditions are manifested in the modal dimension through the modal attributes of the valuating subject, which are present in the theory of the valuative speech acts. These conditions are tightly bound to the modal semantic category of loyalty.

- Essential conditions: in which the person that produces the speech act is conditioned by some beliefs or intentions. In this case, the conditions are also manifested in the modal dimension of the category of valuation through the attributive aspect. Here, the valuating subject assumes a certain position, which is referred to as an appraisal in the illocutionary dimension.

We are going to analyze the modality of speech acts within the most significant utterances to reveal their intentionality, therefore revealing the ideological dimension in a given poem.

Carrying out discourse analysis in poetry is complex because utterances and speech acts are shorter and more concise in a poem; therefore, a lot is said in few words. For this reason, we think it is better and reasonable to analyze what is implicit in the utterances of the poems. For this task, we need to bear in mind three important concepts: Proposition, Presupposition, and Implication (Lyons, 1977).

Proposition:

"Every statement that can be made by uttering a simple sentence expressed a proposition, which, if it is informative, provides the answer to either an explicit or an implicit question" (Lyons, 1977:503)

Presupposition:

What can be logically deduced from what is being said (proposition).

"Eg: In asking What happened? We presuppose minimally that some event or process occurred." (Lyons, 1977: 504)

Implication:

Implication is the message that can be understood although it is not explicitly stated. According to Lyons, "The notion of implicature rests upon a distintion between what is actually said and what is implied in saying what is said" (Lyons, 1977: 592)

\subsection{Ideology, Society and Discourse}

It has been proved that a person's ideology can be perceived through their discourse. According to Van Dijk's approach on ideology and discourse, the study of the ideological 
components of discourse is an attempt towards establishing some kind of relation between discourse and society. He states that:

Ideologies are not merely sets of beliefs, but socially shared beliefs of groups. These beliefs are acquired, used and changed in social situations, and on the basis of social interest of groups and social relations between groups in complex social structures. (1998)

In this concept Van Dijk highlights the fact that ideologies exist within society, expressed by those social groups with shared goals and interests, which are the basis of their actions and thinking, and what make them react, behave and face reality in a particular manner.

Although discourse is conditioned, first by socio-political ideologies, and then by ideological groups, it is important to point out that neither institutions nor organizations emit discourse, but the people who conform them. This way, their discourse will depend on their own way of seeing reality, but always keeping the "essential or core ideological propositions [...] those that are the specific, defying or prototypical fundamental beliefs of a group" (Van Dijk, 1998). In addition, people may be part of different ideological groups during their lives and thus, they may share different ideologies, which, of course, are going to be conveyed, shared, and legitimated through their discourse.

At this point, an important question arises: Can only one group member's discourse represent the ideology of the whole group? In this regard, Van Dijk (1998) expressed that: "A group has an ideology if most of its members share most of the propositions that define such ideology."

Therefore, we assume that despite the fact that an individual may have personal opinions, different from some other members of the group, they still have the basics or the essence of their beliefs as a commonality.

In our intention to demonstrate how the ideology of African-American women as a group is reflected through Alice Walker's poetry, we follow Curbeira's idea that "Ideologies are the bases of the different types of valuation human beings carry out through discourse."(2003) (translated)

However, we have to take into consideration the words of Curbeira when she states that even though ideologies are expressed through discourse, "it does not mean that we can "read" ideologies in discourse". It is deduced from her words that it is important to carry out a semantic analysis to better understand the underlying meaning of an utterance. That is the reason why we are going to use discourse analysis as a tool to achieve our purpose.

\subsection{Valuation in Discourse}

Leandro Caballero in his unpublished monograph "Semiótica y Diccionario" (Semiotics and Dictionary) deals with the caraterization of valuative speech acts. In his theory, modal values have to be precised in research intended to establish the semantic dimensions of subjectivity.

When studying modality, Caballero (2002) states that in order to establish the senses of discourse and the components of the system of language, which can be assumed as modal for its clear basis on the psychological attitudes of the producers of signs and messages, it is necessary to state that the nature of modality is semantic. That is to say, that modality is in 
the meaning of those signs and messages in contrast to others valid modalities in the logical and grammatical dimensions. In like manner, he explained that there is a broad group of modal phenomena. However, we have to deal just with those that are rooted in the semantic content of language as reflection of the subjective position of speakers in language.

Caballero (2002) proposed a conception of meaning in which it is considered as an entity where there are modal, interactive and referential contents inextricably linked that are carried out thanks to grammatical constructive values or resources.

Taking this as starting point, Galbán Pozo (2006) develops four meaning dimensions: modal, illocutionary, referential and grammatical, defining each of the four as follows.

- Modal dimension reflects the noetic features that have to do with the psychological position assumed before what is said in discourse. They materialize in language, which serves as material and semantic support to convey subjectivity in the socialized communicative activity.

- Illocutionary dimension reflects the features transmitting the intentional interactive contents of speech acts.

- Referential dimension frames up the referent features considered by the agents of dictum, that are characterized by a set of features, namely, constitutive, relational, dominion based and taxonomist.

- Constructive-Grammatical dimension explains the morphologic and syntactic rules intervening in the formularization of statements taking the semantic features as a starting point.

In our paper we are going to focus on the modal and the illocutionary dimensions for they are the most useful to our work since this paper is aimed at characterizing the discourse of the valuating subjects in the poems selected according to the intentionality and the modality of discourse. The modal semantic macrocategories we are going to work with are those proposed by the Group of Semantic, Ideographic and Discourse Studies of FLEX: Valuation, Loyalty, Certainty, Expressiveness, Affectivity and Interest.

\section{Valuation:}

It is a modal semantic macrocategory expressing the subjective position of the speaker before what is said on the basis of social standards in which the pragmatic value of objects and phenomena is taken into account. These two final elements classify in a range of axiological values. It can be perceived that the valuation is characterized by the presence of an illocutionary agent that intends to carry out different sorts of valuations that take place in different kinds of valuating speech acts (Galbán, 2006).

The modal semantic macrocategory of valuation is the basic modal category (Galbán 2006) because valuation involves certain grammatical semantic and social values. Valuation reflects the intention of the speaker in saying a particular thing towards the object in question in the process of valuation. That is, any time valuations are carried out; they are going to be conditioned by the perception of the world as well as the social and cultural values of the speaker. 
In terms of the illocutionary dimension, Galbán (2006) speaks about a valuating illocutionary agent (that we are going to identify with the valuating subject, this being the voice of the poem, which in literary terms would be referred to as the poetic persona). The valuating subject is defined as the producer of discourse expressing a communicative intention in which their subjective position with respect to the object under consideration is revealed so as to acknowledge on it a value of a range or socialized standard.

Considering that there are three types of valuating speech acts, Galbán (2006) has defined three types of valuating subjects:

- Evaluator: A discourse producer that, taking as a basis a status people recognize in them, expresses a communicative intention. Here, they expose their subjective position with respect to an object under consideration to emit a valuation in which the value of a range of standard or parametric values (previously established, socialized and linguistically structured) is attributed on it. This way the emitted valuation has a conclusive, transcendent and closed character since this valuation may have certain consequences for the valuated object.

- Appreciator: A discourse producer that does not take into account aspects related to social status. Taking a socialized defused standard as basis, the appreciator expresses a communicative intention in which their subjective position towards the object in question is revealed. The object is intentionally under consideration in order to emit an open and socially inoffensive valuation. So, the attribution or acknowledgement does not have transcendental consequences for the object.

- Hierarchizer: A discourse producer that expresses a communicative intention in which their subjective position towards the object in question is revealed. The object is intentionally under consideration in order to emit a valuation that is carried out establishing a hierarchic order of the object regarding another object or group of objects. These are taken as point of reference to carry out a valuation that will be distinguished by its relative character.

In terms of the axiological aspect, Galbán (2006) recognizes four values: good (favorable), bad (unfavorable), ambivalent (both good and bad), and ambiguous (neither good nor bad).

Loyalty is defined as a modal semantic macrocategory expressing the subjective position of the speaker before what is said in three perspectives depending on the aspect focused. These are: the discursive perspective (referring to the correspondence feeling-discourse), the ethical-intentional perspective (referring to the ethical-intentional aspect), and the cognitiveintellectual perspective (addressing the cognitive-intellectual aspect).

The discursive perspective focuses on the psychological position of the speaker in correspondence to their discourse. This perspective shows two contraries: sincerity vs. insincerity. These two notions are going to be exposed by speakers who express their subjective position towards them, by means of discourse. Under this perspective the valuating subject is going to be either sincere or insincere. We are not going to find contradictories, in part, due to the fact that there are no middle terms in being sincere or insincere.

The ethical-intentional perspective refers to the ethical valuation of the intention expressed by the speaker in their discourse. This perspective states two contraries: good intention vs. bad intention and two contradictories: non-bad intention vs. non-good intention. The 
first pair shows a semiotic balance in which the notion of intentional ambivalence appears. In the case of the second pair, a balance can also be produced; this is shown in the notion of intentional ambiguity.

The cognitive-intellectual perspective reflects the means used by the speaker (valuating subject) in his interaction with other speakers so as to achieve certain purposes. This perspective shows two contraries: astuteness vs. naiveness.

Regarding the illocutionary dimension, there are no specific valuating subjects for this category.

Certainty is defined as a modal semantic category expressing the subjective position of the speaker before what is said on the basis of sureness as a pragmatic value. In the cognitive-discursive perspective, that is translated into sure, clear and evident knowledge of things. On the other hand, in the volitive perspective, that is reflected in the firmness or determination as pragmatic values. The volitive aspect of the subject actions are based on those values.

Under the cognitive-discursive perspective there are two contraries: sureness vs. unsureness and two contradictories: non-sureness vs. non-unsureness. The first pair is going to be expressed in modal attributes of a range of degrees going from a high level of sureness (sure) to the lowest level unsureness (unsure). There is a middle term in between which is ambiguous security. This is going to be determined by a series of hints available for the speaker that make them think of the possibility that something has a certain state although it has not yet been corroborated.

Under the volitive perspective there are two contraries: decision vs. indecision. They reflect the character of individual attitudes (definite vs. indefinite) towards a certain stance to assume. There are no contradictories in this perspective.

With regards to the illocutionary dimension, Galbán (2006) only speaks of valuating subject in the case of inquiring (speech) acts in which, by means of inquiry, the speaker tries to change from an unsureness state to sureness.

The macrocategory of Expressiveness is defined as that expressing the subjective position of the speaker before what is said about objects and phenomena of the reality. This position reveals the emotional state of the speaker in two perspectives: mode of expression and expressed emotional tone.

The mode of expression perspective states two contraries: containment vs. gush and the contradictories: non-gush vs. non-containment. They show the link between the mode of emotion expressions and the socio-cultural models of valuation. Consequently, it is necessary to pay attention to the socio-cultural models established by the different social groups for they play an important role when exteriorizing discourse.

In addition to the notions including this perspective there is a semic balance between non-gush and non-containment which is denominated calm. Here we talk about speakers showing no emotional tension, a neutral position instead. This is a state in which expressiveness is not revealed at all.

Under the expressed emotional tone perspective, Galbán (2006) proposes two contraries: satisfaction vs. dissatisfaction. These replace the ones of laughing and crying established by Caballero (2002) for they are more inclusive as far as position assumed by the speaker on the basis of feelings, emotions, and moods, is concerned. As reflect of the semic balance between contraries, a sentimental ambivalence in which there is a mix of joy and grief. 
This perspective includes two contradictories: non-dissatisfaction vs. non-satisfaction. This time a balance is also produced: indifference. It reflects the combination between the two contradictories in terms of experienced feelings.

With regards to the illocutionary dimension, there is no specific valuating subject or illocutionary agent for this modal semantic macrocategory.

Affectivity is defined as a modal semantic macrocategory expressing the subjective position of the speaker towards what is said on the basis of the affective feelings that objects and phenomena of reality evoke in them.

Here Galbán (2006) includes in a gradual structure three levels of intensity (maximum tension, middle tension and minimum tension) containing three pairs of contraries. They will reflect different levels of tension of affective feelings expressed by speakers: from the most intense tension or level of intensity, love vs. hate, passing by affection vs. disaffection, to the less intense way of tension, pleasure vs. displeasure. In like manner, we are going to find three pairs of contradictories respectively: non-hate vs. nonlove, non-affection vs. non-disaffection, and non-pleasure vs. non-displeasure.

There is no specific valuating subject for this macrocategory. However, illocutionary agents producing different types of speech display some of the modal attributes related to the category of affectivity.

Galbán (2006) defines interest as the expression of the subjective position of the speaker before what is said. This position reveals how reality objects and phenomena cause concentration of attention, expression of mood towards the object or not. All this may constitute an incentive to carry out a conscious act. This macrocategory shows two perspectives: the volitive-actional perspective and the attention perspective.

In the case of the volitive perspective, it is manifested in the degree of volition, whether an action is carried out at will or not. In this perspective, a contrary relation between the two notions of interest and obligation is produced. This combination results in commitment. On the other hand, the relation of contradiction between the notions of non-obligation and non-interest results in the exclusion of interest.

There is also a relation established among contraries and contradictories. On the positive side, when there is interest and non-obligation, the outcome is desire. On the negative side, when there is obligation and non-interest, the outcome is compulsion. Under these relations set out by contraries and contradictories, the interest gradation of human beings is revealed.

The attention perspective refers to the degree of attention towards what is said. In this perspective there is a pair of contraries, interest vs. lack of interest and a pair of contradictories, non-lack of interest vs. non-interest. The relation between the contradictories leads to the notion of indifference.

Regarding the illocutionary dimension, there are not specific illocutionary values assigned to this macrocategory.

\section{Analysis of the Poems}

\subsection{Poem: SONG}

As we all know African - American women have been discriminated against not only for being females, but also for their skin color. Racism is a curse that has affected many 
people in general and black people in particular throughout history. They have been treated as savages, as working animals, as objects whose only purpose in life was serving the white people and making them happy.

There have been plenty of ways of discrimination: hard work, segregation and even the discourse used to address black people. First, they were referred to as negroes and afterwards colored which had a very negative connotation. Then, after the achievements of the Civil Rights Movement, the public opinion started to call the black population People of color. Obviously, this term far from being neutral is rather excluding because it does not include people from other nationalities or other races who evidently have a certain skin color.

This is precisely the main topic of the poem "Song" in which the author uses a sarcastic tone to address this polemic issue.

The author uses this poem to express her concern, and maybe her anger concerning the terms used to denominate black people; that is the reason why she begins the poem with the next utterance that is composed of two speech acts:

\section{Utterance $\mathrm{I}^{3}$}

1. The world is full of colored people

2. People of color

This utterance is a positive valuation, and according to the illocutionary dimension, it is a categorical, physical, and ideological appraisal. We all know that people of color and colored people are excluding terms, only used to refer to blacks, in this poem the valuating subject uses them in an including way instead. That is to say that when she states: the world is full of colored people people of color; she includes people from other races, which is something positive. In this utterance, one of the main aspects of the womanist ideology is present: antiracism.

This time, the valuating subject is sure because she could have used expressions like $a$ lot of, plenty of, a great deal of etc.; however, she uses the categorical adjective full to indicate that every single person on earth has a particular skin color. In addition, another modal attribute accompanying the appraisal inherent to the valuating subject is interest, as to the subjective position of the speaker towards what is being said in the attention perspective. Here, the valuating subject manifests her interest in calling the readers' attention to the issue being raised in the poem by using two terms with a different sense. Likewise, the valuating subject is sincere and expressive, a macrocategory inherent to poetic discourse due to great deal of literary resources used.

In order to support her idea, the valuating subject bases the next utterances on physical traits that characterize people from all races, stating no valuation. We must clear up that we will analyze only the utterances and speech acts we consider relevant to achieve the objective of the work.

Utterance II

1. They have black hair and black and brown eyes.

3 Roman numerals for utterances and cardinal numbers for speech acts. 
Utterance III

1. Their skins are pink and yellow and brown

Utterance IV

1. Some have full lips

2. Some have thin

What she wants to highlight with these three utterances is that we can find different skin colors and physical traits that belong to all races around the world.

Finally, the author uses the phrase Colorful people (utterance V) which is actually the most important utterance of the poem. Even though this phrase may seem to be another variant of the previously analyzed expressions, there is a positive approach in it, because the author wants to convey the idea that all skin colors are equally beautiful and important, and that we should not find in color a way to discriminate others against. Color is what provides the world with variety and people, far from being embarrassed, should be proud of their skin color and should have others feel the same.

That is why we consider this is a positive valuation and the appraisal is physical and ideological. Furthermore, the valuating subject is sure, categorical, expressive, sincere, and well-intended, since with the expression colorful people, she is trying to erase discourse discrimination when addressing black people.

\subsection{Poem: Torture}

Throughout the history of human kind there have been people who have devoted their lives to causing harm to others, whereas there have been others who have always worked hard for the sake of a better society. Destruction, pain, and suffering have been the main goals of a minority who believe themselves to be superior, and thus, discriminate against and sometimes exterminate a big sector of society whose only sin has been the fact of being poor, black, woman or child. Fortunately, there has always been a response: endurance. That is precisely the main topic of this poem since the author is encouraging the oppressed to resist and never give up trying as far as their rights are concerned.

The poem is divided into six utterances and thirteen speech acts, one of which is repeated five times through the poems.

Utterance I.

1. When they torture your mother

2. Plant a tree.

Utterance II.

1. When they torture your father

2. Plant a tree.

Utterance III

1. When they torture your brother and your sister

2. Plant a tree 


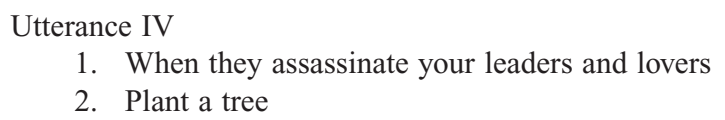

Utterance $\mathrm{V}$

1. When they torture you too bad to talk

2. Plant a tree

Utterance VI

1. When they begin to torture the trees

2. and cut down the forest they have made

3. start another

The six utterances of the poem are divided into two different kinds of speech acts. The first ones are assertive, and the valuating subject is addressing an adverse reality in which negative actions are raised. Thus, these valuations are generally negative, categorical and physical appraisals.

In the first five utterances, the valuating subject introduces words like mother, father, brother, sister, leaders, and lovers, in an attempt to point out relevant symbols in people's life; leaving the final spot to the personal approach. If we address the poem as a whole without splitting the analysis, we can evidence the use of these elements in a multiple consecutive hierarchical fashion, narrowing the field of action until there is nothing else left to torture.

Meanwhile, the second speech act in utterances I to V, and the third one in utterance VI are directive ones, calling the target reader to react positively in response to the aggression stated in the previous speech acts. The valuating subject uses the phrase plant a tree as a symbol, meaning carrying out good and pacific actions. Trees, as part of nature, are associated with strength, long life and hope. In addition, the final speech act of the poem: Start another, reinforces the idea of endurance, thus introducing the aspect of the womanist ideology present in the poem.

These speech acts are positive and ideological appraisals being modalized by the presence of modal macrocategories as in the case of certainty, for the valuating subject is sure of the issues she is stating in a categorical and factual way. Likewise, she is optimist and determined to never give up no matter how difficult the situation may be, well-intended and interested in having readers resist.

Furthermore, the macrocategory of expressiveness is a central element to be taken into consideration when approaching poetry, since the word choice is really detailed and most of the times combined with the implicit messages the author wants to convey, bringing a great deal of subjectivity into the discourse and allowing the readers to come up with their own interpretations. In the case of the first speech act in utterance number $\mathrm{V}$, the valuating subject uses the word too which besides having negative semes like: in excess; to such a degree as to be regrettable, also entails a certain degree of gushing.

\subsection{Poem: A woman is not a potted plant}

Sexism is another issue African - American women have faced throughout history. Black women have been doubly discriminated against, for being women and for being black. This 
issue has made black women's struggle harsher. Men have always treated women as the weak sex; moreover, black women have been tacitly confined to "ladies' work", and they have usually played that role restrained and fearful of fighting for their rights.

That is precisely what Alice Walker conveys through the poem's valuating subject.

\section{Utterance I}

1. a woman is not a potted plant

In spite of the fact that it is a negative, assertive speech act, this is a positive valuation where the valuating subject refuses to acknowledge a negative characteristic attributed to women. This is a moral and ideological appraisal since the valuating subject is implying that women are not only pretty faces that may be used to decorate places, unable to speak and come up with reasonable arguments; instead, they also have values, wishes, opinions and concerns.

Concerning the valuating subject, we could say that she is appraiser, sure, interested, expressive, and well-intended. Sure because she states the utterance as a fact, interested because she explicitly wants others to realize what women actually are by showing what they are not, repeating the utterance three times along the poem. Finally, there is expressiveness since the valuating subject could have used expressions like decorative object or ornament, but instead she uses potted plant to make the identification more vivid and also to activate semes like being ordinary and dependent on others' care.

In the following utterances, the speaker establishes a comparison based on the similarities potted plants and women may have:

\section{Utterance II}

1. her roots bound to the confines of her house

In this utterance, the speaker uses the word bound, which implies tied, fastened, fixed, and joined, giving the message that women are supposed to be attached to their houses as plants to their pots.

Utterance IV

1. her leaves trimmed to the contours of her sex

In this case, the speaker uses the verb to trim to imply that women are kept from performing multiple activities due to their female condition. However, at the same time, society obliges them to carry out other functions like raising their children and taking care of their house as if other members of the family did not have the same amount of responsibility.

Utterance VI

1. her branches espaliered against the fences of her race her country her mother her men

In this utterance, the speaker is trying to convey the idea that black women's world is composed and ruled by everything that implies being black, living in such a country like the United States, and always bearing in mind the submissive, male-centered education they received from their mothers. 


\section{Utterance VII}

1. her trained blossom turning this way \& that to follow the sun of whoever feeds and waters her

This time, the speaker is trying to imply that submissive women, like plants, try to be always attached to those who support them, as if they were incapable of standing up for themselves.

These four utterances are made of assertive, negative speech acts since the valuating subject is giving different characteristics potted plants and women may have in common in order to highlight the negative aspects that others (usually men) use to minimize women's values. In addition, the appraisal is moral, and ideological. Moral, because they refer to the negative moral values certain sectors of society embrace. Ideological, for it portrays the male-chauvinist ideology still vivid in the minds of a great deal of the society.

The valuating subject is appraiser, sure, expressive, interested, and well-intended. Sure, because the valuating subject is very aware of what she is saying. Expressiveness is evidenced in the metaphors used to refer to women and their situation. Besides, the valuating subject shows interest in having readers reflect on the fact she is introducing. Finally, the valuating subject is well-intended for she is criticizing the state of affairs and drawing people's attention towards the fact.

Hence, the last utterance is of a great importance since it specifies the valuating subject's position concerning the main topic of the poem.

Utterance VIII

1. a woman is wilderness unbounded

2. holding the future between each breath

3. walking the earth only because she is free and not creepervine or tree. Nor even honeysuckle or bee.

Here, the valuating subject finally introduces her moral and ideological position towards the issue. Anti-sexism is evidently one of the banners held by the Womanist Movement along the years. This final utterance clearly states the idea of women being able to think by themselves, to make decisions, to walk the earth with their own feet. Besides, they are the sources of life; that is why they deserve respect, affection and wings to fly.

These final speech acts are assertive, positive appraisals. They are moral, categorical and ideological. The valuating subject is also appraiser, sure, well - intended, interested, and gushing marked by the use of the adjective unbounded (having or appearing to have no limits).

\section{Conclusions}

In this Paper, we have tried to identify the presence of the womanist ideology in Alice Walker's poems by analyzing the discourse of the valuating subject. This research has been a big challenge since there was no antecedent with this approach, combining the ideological discourse analysis to the modal semantic macrocategories using poetry as the object of study. Contrary to what some people might believe, analyzing poetry is not an easy task, let alone when you have to identify the implicit information in discourse to describe the valuating subject. 
After having analyzed three poems of the book Her blue body Everything we know, we were able to describe the different positions assumed by the valuating subjects, which we assume were African Americans for the correlation established between the author, the message, the content of the poems and the audience being targeted. The ideological aspects of the Womanist Movement identified in the three poems by Alice Walker are: antiracism, endurance, and antisexism; which are some of the foundations of this movement.

The analysis yielded that concerning the illocutionary dimension no evaluations were identified. Most of the valuations were appraisals, and there was only one multiple-consecutive hierarchization. Additionally, the valuations were generally positive and the appraisals were mostly moral, physical and ideological. Concerning the modal dimension, the valuating subjects were mostly appraiser, expressive, interested, sure and well-intended. Concerning the semantic category of interest, we arrived at the conclusion that in Alice Walker's poems the valuating subject is most of the times interested for there is a marked intention to have readers reflect on the ideological message she is conveying. We know that it is very difficult to find interest in poetry. However, if we follow the principle of analyzing the implicit ideological message being conveyed in the poems, based on the presuppositions and implications of the utterances, it is not difficult to identify the underlying interest of the valuating subject in drawing the readers' attention towards the message of the poem. That is why we consider that the semantic category of interest should be taken into account when analyzing poems that convey ideological messages.

\section{Bibliography}

Austin, J.L. (1962): How to Do Things with Words. Oxford, Clarendon Press.

Caballero Díaz, Leandro (2002): Modalidades Semánticas del Lenguaje. (Monografía inédita) Facultad de Lenguas Extranjeras, Universidad de la Habana.

Chafe, William H. (1977): Women and Equality. Oxford, Oxford University Press

Charaudeau, Patrick. (1998): “Las grandes problemáticas del análisis de discurso”. México, Revista: Estudios de Lingüistica Aplicada, Núm. 27.

Curbeira Cancela, Ana (2003): Lecturas de Semántica. La Habana, Félix Varela.

Curbeira Cancela, Ana (2007): Introducción a la Teoría del Lenguaje. La Habana, Félix Varela.

Eliot, Samuel y Stele, Henry (1951): Historia de Estados Unidos de Norteamérica. México, Fondo de Cultura Económico Panuco.

Fernández Gayol, Manuel (1945): Teoría Literaria. La Habana, El siglo XX.

Fowler, Roger (1996): Linguistic Criticism. USA, Oxford University Press.

Frazier, Thomas R. (1971): Afro-American History: Primary Sources, Harcourt Brace Jovanovich. Galbán Pozo, Ana María (2007): Categorías Semánticas Valorativas. (Tesis doctoral inédita)

Facultad de Lenguas Extranjeras, Universidad de la Habana.

Hatim, Basil and Mason, Ian (2013): Discourse and the Translator. New York, Routledge. Ivanov, R. (1979): La Historia de Estados Unidos y el Problema Negro. La Habana, Ciencias Sociales.

Lions, John (1977): Semantics 2. Cambridge, Cambridge University Press.

Meyer, Michael (1993): The Bedford Introduction to Literature II. Third edition. Bedford, Saint Martins. 
Moi, Toril (1985): Sexual and Textual Politics. Feminist Literary Theory. London \& New York, Loulettge.

O’Relly, Richard (1984): El Pueblo Negro de Estados Unidos: Raíces Históricas de su Lucha Actual. La Habana, Ciencias Sociales.

Parrilo, Vincent N. (1990): Strangers to these shores. New York: McMillan.

Rowbothom, Sheila (1972): Women, Resistance and Revolution. New York, Random House, Inc.

Schneir, Miriam (1994): Feminism: The essential Historical writings. New York, Vintage Books.

Searle, J. (1969): Speech Acts. Cambridge, C.U.P.

Van Dijk, T. (1998): A Multidisciplinary Approach. Great Britain, The Cromwell Press

Walker, Alice (1974): In Search of our Mothers' Gardens: Womanist Prose. Florida, HBJ.

Walker, Alice (1993): Her Blue Body Everything We Know: Earthling poems. USA, Harcourt Brace and Company.

Webster's Dictionary Seventh New Collegiate Edition (2003). La Habana, Felix Varela.

Zinn, Howard (2004): La otra cara de los Estados Unidos. La Habana, Ciencias Sociales.

\section{Internet Sites:}

Alice Walker Poetry: American Poets Analysis: http://www.enotes.com/topics/alice-walker/ critical-essays/analysis-3 (04-11-2006)

But Some of Us Are Brave: A History of Black Feminism in the United States. http://www. mit.edu/ thistle/v9/9.01/6blackf.html (05-01-2006)

Civil Rights Movement. http://www.history.com/topics/black-history/civil-rights-movement (01-11-2006)

Thomas E. Linda: Womanist Theology, Epistemology, and a New Anthropological Paradigm. http://www.crosscurrents.org/thomas.htm (04-12-2006)

Women's History in America. http://www.wic.org/misc/history.htm (01-11-2006) 


\section{Song}

The world is full of colored

People

People of color

Tra - la -la

The world is full of

Colored people

Tra - la - la -la - la

They have black hair

And black and brown

Eyes

The world is full of

Colored people

Tra - la - la

The world is full of colored

People

People of color

Tra - la - la

The world is full of colored

People

Tra - la - la - la - la

Their skins are pink and yellow and brown

all colored people

people of color

colored people

tra - la-la

Some have full lips

Some have thin

Full of colored people

People of color

Colored lips

Tra - la - la

The world is full of

Colored people

People of color

Colorful people

Tra - la - la!

\section{Torture}

When they torture your mother

Plant a tree

When they torture your father

Plant a tree

When they torture your brother

And your sister

Plant a tree

When they assassinate

your leaders

and lovers

plant tree

when they torture you

too bad

to talk

plant a tree

when they begin to torture

the trees

and cut down the forest

they have made

start another
A women is not a potted plant

her roots bound

to the confines

of her house

a women is not

a potted plant

her leaves trimmed

to the contours

of her sex

a woman is not

a potted plant

her branches

espaliered

against the fences

of her race

her country

her mother

her men

her trained blossom

turning

this way

\& that

to follow

the sun

of whoever feeds

and waters

her

a woman

is wilderness

unbounded

holding the future

between each breath

walking the earth

only because

she is free

and not creepervine

or tree.

Nor even honeysuckle

or bee. 